\title{
Erythrocytosis and iron status in Eisenmenger syndrome: an illustrative case study
}

\author{
Robin Condliffe
}

\begin{abstract}
Background: Patients with Eisenmenger syndrome are chronically hypoxaemic and should therefore mount a secondary erythrocytosis. This response can be attenuated by iron deficiency. Historically, patients with Eisenmengerassociated erythrocytosis often underwent venesection but recent data have challenged this practice.

Case presentation: An illustrative case of a 30-year-old female with Eisenmenger syndrome secondary to a ventricular septal defect is discussed. Her resting saturations on room air were $84 \%$. She was receiving pulmonary arterial hypertension targeted therapy with sildenafil $25 \mathrm{mg}$ three times a day and bosentan $125 \mathrm{mg}$ twice daily. Her local haematologist was planning on therapeutic venesection as her haematocrit was elevated at 0.57 . Her haemoglobin was $16.7 \mathrm{~g} / \mathrm{d}$, ferritin levels were $15 \mu \mathrm{g} / \mathrm{L}$ and transferrin saturations were $10.5 \%$. What are the indications for venesection? Should she receive iron supplementation instead? Data to help guide decision-making are reviewed and a clinical approach is suggested.

Conclusions: Iron status should be regularly checked in Eisenmenger syndrome patients and replaced appropriately. There is no role for routine venesection in patients with Eisenmenger syndrome; this should be reserved for the small proportion of patients with symptoms of hyperviscosity in the absence of dehydration.
\end{abstract}

Keywords: Erythrocytosis, Polycythaemia, Eisenmenger syndrome, Iron, Pulmonary hypertension

\section{Background}

Patients with Eisenmenger syndrome (ES) are chronically hypoxaemic and should therefore mount a secondary erythrocytosis. This response can be attenuated by iron deficiency. Historically, patients with Eisenmengerassociated erythrocytosis often underwent venesection, but recent data have challenged this practice. In this paper, a case of a patient with ES secondary to a ventricular septal defect (VSD) is presented. The clinical details described in this illustrative case are based on experience gained from multiple patients. Data to help guide decision-making are reviewed and a clinical approach is suggested.

\section{Correspondence: robin.condliffe@sth.nhs.uk}

Pulmonary Vascular Disease Unit, Royal Hallamshire Hospital, Sheffield S10 2JF, UK

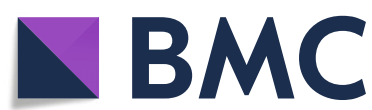

\section{Case presentation}

This is the case of a 30-year-old female who had moved to the UK from the Indian sub-continent at the age of 18. A VSD was identified during childhood but closure was not performed. She was subsequently diagnosed with ES and commenced pulmonary arterial hypertension targeted therapy in 2007 in the form of bosentan $125 \mathrm{mg}$ twice daily (bd), with symptomatic and functional benefit. In 2012, sildenafil $25 \mathrm{mg}$ three times daily (tds) was added due to symptomatic worsening, again with benefit. Over the last year she had complained of some worsening of breathlessness but denied any headaches or overt lethargy. She had regular periods, which were not particularly heavy, and had no other history of bleeding. Her only other medication was desogestrel of which she took 2 tablets daily in view of the potential interaction with bosentan.

(c) The Author(s). 2020 Open Access This article is licensed under a Creative Commons Attribution 4.0 International License, which permits use, sharing, adaptation, distribution and reproduction in any medium or format, as long as you give appropriate credit to the original author(s) and the source, provide a link to the Creative Commons licence, and indicate if changes were made. The images or other third party material in this article are included in the article's Creative Commons licence, unless indicated otherwise in a credit line to the material. If material is not included in the article's Creative Commons licence and your intended use is not permitted by statutory regulation or exceeds the permitted use, you will need to obtain permission directly from the copyright holder. To view a copy of this licence, visit http://creativecommons.org/licenses/by/4.0/ The Creative Commons Public Domain Dedication waiver (http://creativecommons.org/publicdomain/zero/1.0/) applies to the data made available in this article, unless otherwise stated in a credit line to the data. 
On examination, her resting saturations $\left(\mathrm{SaO}_{2}\right)$ on room air were $84 \%$. Her heart rate was 72 beats per minute and blood pressure $135 / 70 \mathrm{mmHg}$. She was clubbed. She had no peripheral oedema and her jugular venous pressure was not elevated. She had a systolic murmur at the left lower sternal edge and had a loud P2. Her chest was clear.

Electrocardiogram demonstrated sinus rhythm with right axis deviation and inferior and anterior $\mathrm{T}$ wave inversion. Chest X-Ray demonstrated cardiomegaly with enlarged central pulmonary arteries. Echocardiography demonstrated mild right atrial dilatation, a hypertrophied and mildly dilated right ventricle with preserved systolic function, normal-sized left atrium and ventricle with preserved left ventricular systolic function. A large VSD was noted with a predominant right-to-left shunt. Moderated tricuspid regurgitation was present with a maximum regurgitant velocity of $4.8 \mathrm{~m} / \mathrm{s}$ giving an estimated systolic pulmonary arterial pressure of $92 \mathrm{mmHg}$ plus right atrial pressure. She walked $375 \mathrm{~m}$ on the incremental shuttle walk test with $\mathrm{SaO}_{2}$ falling to $70 \%$.

She had previously been found to have an erythrocytosis and, in view of her worsening symptoms, her local haematologist was planning on performing therapeutic venesection. Haemoglobin concentration was $16.7 \mathrm{~g} / \mathrm{dL}$, with a haematocrit of 0.57 and a mean corpuscular volume (MCV) of $86 \mathrm{fL}$. Platelets were reduced at 115,000/mL and she had a normal white cell count. Ferritin levels were 15 microgram/L and transferrin saturations were also low at $10.5 \%$. Serum folate and vitamin B12 levels were normal.

Her haematologist was advised to cancel the venesection and instead she was commenced on iron supplementation in the form of ferrous sulphate $200 \mathrm{mg}$ tds. After 3 months her haemoglobin level had increased to $18.9 \mathrm{~g} / \mathrm{dL}$ and haematocrit had increased to 0.6. Her ferritin level had also increased to $95 \mu \mathrm{g} / \mathrm{L}$ and transferrin saturations were now within normal limits at $21 \%$. Her incremental shuttle walking distance had increased to $410 \mathrm{~m}$ and she reported improvement in her breathlessness on exertion.

\section{Discussion}

ES is characterised by elevated pulmonary vascular resistance resulting in chronic hypoxaemia due to right-toleft shunt through an intracardiac defect or persistent ductus arteriosus. Oxygen delivery $\left(\mathrm{DO}_{2}\right)$ can be described by the equation:

$$
\mathrm{DO}_{2}=\mathrm{CO} \times \mathrm{CaO}_{2}
$$

Where $\mathrm{CO}$ is cardiac output and $\mathrm{CaO}_{2}$ is systemic arterial oxygen content. $\mathrm{CaO}_{2}$ is described as:

$$
\mathrm{CaO}_{2}=\text { oxygen saturation } \mathrm{x} \text { haemoglobin }(\mathrm{g} / \mathrm{dL}) \times 0.0134
$$

In an effort to maintain systemic oxygen content and hence physiological homeostasis, ES patients should therefore develop a compensatory secondary erythrocytosis. This results in a raised haematocrit with an associated increase in whole blood viscosity (WBV) [1], which may promote hyperviscosity symptoms and increase right ventricular (RV) afterload [2, 3]. Furthermore, it has been feared that the erythrocytosis may promote thrombotic events, similar to patients with polycythaemia due to myeloproliferative disease [4]. Consequently, historical standard practice was to venesect patients with ES to reduce the risk of thrombotic events, especially stroke. Several studies have, however, challenged this practice. In an observational study of 162 patients with ES, Ammash et al observed that the risk of stroke was actually increased in patients with low MCV and previous venesection [5]. Van De Bruaene et al subsequently studied 68 ES patients and observed worse outcomes in patients with iron deficiency [6]. They also found that iron deficiency was more common in patients who had undergone venesection or were receiving anticoagulation therapy. Tay et al. studied 25 patients with cyanotic congenital heart disease and demonstrated improved exercise capacity and quality of life following iron replacement [7]. As such, current guidelines advise against routine venesection in patients with ES [8].

Certain patients with symptoms of hyperviscosity (such as headache, dizziness and lethargy) in the absence of dehydration may benefit from venesection; typically these patients will have a haematocrit $>0.65$ [9]. Similar symptoms can, however, develop in patients with iron deficiency and venesection should not be performed in the context of iron depletion [1]. Selection of symptomatic patients for venesection is, therefore, not straightforward and should only be repeated if associated with definite symptomatic improvement. When performed, crystalloid should be infused to match the volume of blood removed: "isovolumic venesection" [10]. An additional rare indication for venesection is to augment platelet numbers pre-operatively.

Instead of venesection, the more common treatment decision in patients with ES is commencing iron supplementation. Diller et al studied 171 ES patients and observed a positive correlation between resting peripheral oxygen saturations and haemoglobin levels in iron replete patients, which was not present in iron deficient patients [11]. Broberg et al subsequently studied 65 ES patients and derived a predictive equation for haemoglobin concentration in the presence of normal iron studies and vitamin B12 and folic acid levels:

$$
\text { Predicted haemoglobin }(\mathrm{g} / \mathrm{dL})=61-\left(\mathrm{SaO}_{2} / 2\right)
$$

Our patient with resting $\mathrm{SaO}_{2}$ of $84 \%$, therefore, had an expected haemoglobin concentration of $19 \mathrm{~g} / \mathrm{dL}$ and was appropriately commenced on iron supplementation. 
Although there is a concern of an over-exuberant response to iron supplementation, resulting in a "rebound erythrocytosis" and development of hyperviscosity symptoms, Tay et al observed no symptoms attributed to hyperviscosity in 23 patients following 3 months of oral iron supplementation with ferrous fumarate $200 \mathrm{mg}$ tds [7]. Some patients tolerate even low-dose oral iron supplementation poorly and intravenous iron replacement may be required. Blanche et al recently reported on the safety of intravenous iron supplementation (in the form of iron carboxymaltose in their case - other forms of intravenous replacement are available) in cyanotic patients with pulmonary hypertension and/or congenital heart disease [12].

\section{Conclusion}

The normal response to chronic hypoxaemia in ES is a secondary erythrocytosis, but this response may be blunted in the presence of iron deficiency. Iron status should, therefore, be regularly checked in ES patients and replaced appropriately. There is no role for routine venesection in patients with ES; this should be reserved for the small proportion of patients with symptoms of hyperviscosity, in the absence of other causes.

\section{Abbreviations \\ $\mathrm{CaO}_{2}$ : Oxygen concentration; $\mathrm{CO}$ : Cardiac output; $\mathrm{DO}_{2}$ : Oxygen delivery; ES: Eisenmenger syndrome; MCV: Mean corpuscular volume; RV: Right ventricle; $\mathrm{SaO}_{2}$ : Systemic oxygen saturation; VSD: Ventricular septal defect; WBV: Whole blood viscosity}

\section{Acknowledgements}

Not applicable.

\section{About this supplement}

This article has been published as part of Journal of Congenital Cardiology Volume 4 Supplement 1 2020: Unmet needs in Pulmonary Hypertension associated with Adult Congenital Heart Disease (ACHD-PH). The full contents of the supplement are available at https://jcongenitalcardiology. biomedcentral.com/articles/supplements/volume-4-supplement-1.

\section{Author's contributions}

The author was fully responsible for the design and writing of this article. The author(s) read and approved the final manuscript.

\section{Funding}

Medical writing support was provided by nspm Itd, Meggen, Switzerland. The manuscript was funded by a Medical and Educational Goods and Services (MEGS) grant and Actelion Pharmaceuticals UK Limited (who had no influence on manuscript writing).

\section{Availability of data and materials \\ Not applicable.}

Ethics approval and consent to participate

No ethics approval was required.

\section{Consent for publication}

The clinical details in this illustrative clinical case are based on experience gained from multiple patients. No consent was therefore necessary.

\section{Competing interests}

$\mathrm{RC}$ has received honoraria for lecturing and advisory boards from Actelion, Bayer, GSK and MSD.
Received: 12 November 2020 Accepted: 12 November 2020

Published: 16 December 2020

\section{References}

1. Broberg CS, Bax BE, Okonko DO, Rampling MW, Bayne S, Harries C, et al. Blood viscosity and its relationship to iron deficiency, symptoms, and exercise capacity in adults with cyanotic congenital heart disease. J Am Coll Cardiol. 2006;48(2):356-65.

2. Westerhof N, Elzinga G, Sipkema P. An artificial arterial system for pumping hearts. J Appl Physiol. 1971;31(5):776-81.

3. Tedford RJ. Determinants of right ventricular afterload (2013 Grover conference series). Pulm Circ. 2014;4(2):211-9.

4. McMullin MF, Harrison CN, Ali S, Cargo C, Chen F, Ewing J, et al. A guideline for the diagnosis and management of polycythaemia vera. A British Society for Haematology guideline. Br J Haematol. 2019;184(2):176-91.

5. Ammash N, Warnes CA. Cerebrovascular events in adult patients with cyanotic congenital heart disease. J Am Coll Cardiol. 1996;28(3):768-72.

6. Van De Bruaene A, Delcroix M, Pasquet A, De Backer J, De Pauw M, Naeije $\mathrm{R}$, et al. Iron deficiency is associated with adverse outcome in Eisenmenger patients. Eur Heart J. 2011;32(22):2790-9.

7. Tay EL, Peset A, Papaphylactou M, Inuzuka R, Alonso-Gonzalez R, Giannakoulas $\mathrm{G}$, et al. Replacement therapy for iron deficiency improves exercise capacity and quality of life in patients with cyanotic congenital heart disease and/or the Eisenmenger syndrome. Int J Cardiol. 2011;151(3): 307-12.

8. Galie N, Humbert M, Vachiery JL, Gibbs S, Lang I, Torbicki A, et al. 2015 ESC/ ERS guidelines for the diagnosis and treatment of pulmonary hypertension: the joint task force for the diagnosis and treatment of pulmonary hypertension of the European Society of Cardiology (ESC) and the European Respiratory Society (ERS): endorsed by: Association for European Paediatric and Congenital Cardiology (AEPC), International Society for Heart and Lung Transplantation (ISHLT). Eur Heart J. 2016;37(1):67-119.

9. Spence MS, Balaratnam MS, Gatzoulis MA. Clinical update: cyanotic adult congenital heart disease. Lancet. 2007;370(9598):1530-2.

10. Thorne SA. Management of polycythaemia in adults with cyanotic congenital heart disease. Heart. 1998;79(4):315-6.

11. Diller GP, Dimopoulos K, Broberg CS, Kaya MG, Naghotra US, Uebing A, et al. Presentation, survival prospects, and predictors of death in Eisenmenger syndrome: a combined retrospective and case-control study. Eur Heart J. 2006;27(14):1737-42.

12. Blanche C, Alonso-Gonzalez R, Uribarri A, Kempny A, Swan L, Price L, et al. Use of intravenous iron in cyanotic patients with congenital heart disease and/or pulmonary hypertension. Int J Cardiol. 2018;267:79-83.

\section{Publisher's Note}

Springer Nature remains neutral with regard to jurisdictional claims in published maps and institutional affiliations.
Ready to submit your research? Choose BMC and benefit from:
- fast, convenient online submission
- thorough peer review by experienced researchers in your field
- rapid publication on acceptance
- support for research data, including large and complex data types
- gold Open Access which fosters wider collaboration and increased citations
- maximum visibility for your research: over $100 \mathrm{M}$ website views per year
At BMC, research is always in progress.
Learn more biomedcentral.com/submission 